\title{
Düşünümsel Sosyoloji Açısından Zygmunt Bauman Sosyolojisi
}

\author{
Erdinç KİNEŞÇi \\ Karamanoğlu Mehmetbey Üniversitesi,Edebiyat Fakültesi,Sosyoloji Bölümü,Karaman
}

\section{Özet}

Sosyolojinin kendi üzerinde durup derin bir biçimde eleştirel değerlendirme yapması olarak karakterize edebileceğimiz düşünümsel sosyoloji, yirminci yüzyılın ikinci yarısından itibaren belirmeye bașlamakla birlikte seksenli yıllarda baskın bir biçimde kendinden söz ettirir. Bu çerçevede çağımızın önemli ve etkili sosyal bilimcilerinden biri olan Zymunt Bauman kuşkusuz düşünümsel sosyolojide eleştirel bir duraktır. Bir başka deyişle Bauman çağını sorgularken etik meselesine ayrı bir önem verir. Bauman kültür ve iktidarın çözümlemesine de özel önem vermiş ve bu bağlamda toplum, ideolojiler, ulusal kimlikler, devlet, sosyalizm, ütopya, ahlaki seçim, modernizm ve postmodernizm konularında yorumlamalarıyla sosyal bilimlere düşünümsellik açısından yeni bir soluk getirmiştir. Mevcut sosyolojiye yönelik eleştirel yorumlamaları, düşünümsel çabaları, kendine özgü metaforlarla yüklü diliyle Bauman sosyolojisi nihayetinde postmodern etik nosyonuyla biçimlenmiş ve sosyolojinin eleștirileri bu zeminde yapılmıștır. Bu çalıșmada onun düșünümsel sosyolojisi, önemi belirli birtakım eserleri ışı̆̆ında yorumlanmış ve değerlendirilmiştir. Dolayısıyla yöntem olarak metin incelemesi tercih edilmiştir. Çalışma Bauman literatürüne genel bir bakıș olarak görülebilir.

Anahtar Kelimeler: Düşünümsel Sosyoloji, Eleştirel Sosyoloji, Modernite, Postmodernite, PostmodernEtik, Zygmunt Bauman.

\section{Zygmunt Bauman Sociology in terms of Reflexive Sociology}

\begin{abstract}
Reflexive sociology that we can characterize as sociology to stand on its own and perform a deep critical evaluation, dominantly in the eighties was told about itself along with becoming visible from the second half of the twentieth century. Within this scope, Zygmunt Bauman who is one of the important and influential social scientists of our time is undoubtedly an important critical stand within these discussions. In other words, When Bauman interrogates his age, he attaches special importance to the issue of ethics. Bauman also gave special importance to the analysis of culture and power and in this regard, he brought a new breath of thought to social sciences through his interpretations in terms of reflexivity in the fields of society, ideologies, national identities, state, socialism, utopia, moral choice, modernism and postmodernism. Bauman's sociology which are with critical interpretations for current sociology, reflexive efforts, the language loaded with his specific metaphors shaped by postmodern ethical notion ultimately and criticism of sociology was made on this ground. In this study, his reflexive sociology, in the light of particular number of important works, has been interpreted and evaluated. Therefore, textual analysis is preferred as the method. The study can be seen as a general overview of the Bauman's literature.
\end{abstract}

Keywords: Reflexive Sociology, Critical Sociology, Modernity, Postmodernity, Postmodern Ethics, Zygmunt Bauman

\section{Giriş}

Bauman, son dönemde en azından 70'lerin ikinci yarısı ve 80'li yılların başlarından itibaren sınırları ve etkisi sosyoloji disiplinini aşan geniş bir ilgi odağı ve çözümleme zenginliği ile karşımıza çıkmaktadır. Sosyolojinin ilk kurucularıyla, eserlerinde hesaplaşmakta yani K.Marx, E.Durkheim M.Weber ve G.Simmel'in tespitleri ve değerlendirmeleri ile tartışarak sosyolojik çözümlemelerini açmaktadır. ${ }^{1}$ Yeni ifade

1 Ayrıca, Bauman'ın entelektüel kökenlerinde zengin okumalar bulunmaktadır. Onun, mevcut eleştirel değerlendirmeleri yapmasını sağlayan bir bakıma bu kaynaklardan beslenmesidir. Eserlerinde sıklıkla bu kaynakla çerçevesinde yürüttüğü tartış ma ve incelemeleri gözlemleyebiliriz. Etik tartışmalarda temelde, Emmanuel Levinas, HansJonas, diğer alanlar (felsefe, polita, sosyal olanla ilintili) ve sorunsallarda başta; A.Gramsci, G.Simmel, M.Foucault, J.Derrida, J.Baudirillard. P.Bourdieu, N.Ellias, T.Adorno, M.Horkheimer ,H.Arendt, W.Benjamin ,F.Barth, C.Geertz, M.Douglas, R.Rorty olmak üzere birçok düşünür,teorisyen ve yazarın isimlerine rastlarız. Çağımızın bir diğer sosyoloğu olan Bourdieu 'da Düşünümselliğe sosyoloji pratiği açısından önem verilmesi gerektiğini vurgulayan bir isimdir. Karakayalı'nın (2007:230) belirttiğine göre Bourdieu'nün "her sosyologun kendi sosyolojik pratiğinin sosyal koşullarını irdelemek amacıyla yürüttüğ sosyoloji"olarak tanımladığı "sosyolojinin sosyolojisi”" yani düşünümsellik ilkesi Bourdieu'nun temel yaklaşım noktalarından birini oluşturur. biçimleri ve sosyal bilimlerde yeni açılımlar ve mevcut kriz durumlarından “çıkış" arayışları Bauman'ın çözümlemelerinde yerini almaktadır. Özellikle modernite çerçevesinde yürüttüğü eleştirel yaklaşımları kanımca sosyolojinin düşünümselliği üzerine zihin ve ufuk açıcı katkılarda bulunmaktadırlar. $\mathrm{Bu}$ makalenin vurguda bulunduğu kısım tam da Bauman'ın eleştirelliği bağlamında düşünümsel sosyoloji olarak değerlendirebileceğimiz bir konuya denk düşmektedir. Düşünümsel sosyoloji; bu yazı çerçevesinde sosyolojinin ontolojik, epistemolojik ve metodolojik temellerde durup derin bir eleştirel düşünme ve değerlendirme faaliyeti olarak tanımlanmaktadır. Bir başka ifadeyle sosyolojinin sosyolojisini yani bir bilimsel disiplinin eleştirel yorumlarını ve değerlendirmeleri yapmaktır. Bauman değişen, farklılaşan dünya ve insanlık koşulları, durumları, kayganlaşan zeminler, modernitenin bilinen tüm referanslarının sorgulanıp kriz durumunun çözümlenmesi ve bütün bunların ötesinde farklı açılımlar, değerlendirmeler gerçekleştirme hususunda sosyal bilimlere modernitenin bilim anlayışından farklı sorumluluklar yüklemiştir ve farkındalık yaratmanın sosyal bilimlerin değerlendirmeleri ve 
çözümlemeleriyle yapılabileceğini düşünmüștür. $\mathrm{Bu}$ bağlamda Bauman'in yorumları çerçevesinde oluşturduğu özel yaklaşıma onun belirli vurgularda bulunduğu konulara, temel fikirlerine ve önerdiklerine odaklanılarak düşünümsel sosyoloji açısından öneminin ve farklılı̆̆ının altı çizilecektir. $\mathrm{Bu}$ makale, sosyolojide ve diğer sosyal bilimlerde düşünümsellik meselesine dikkat çekip, belirli okuma ve tartışmaları başlatırsa amacına ulaşacaktır.

\section{Bauman'ın Modernite Anlayıșı}

Bauman, düşünümsellik çerçevesinde en temel olarak yazılarında modernitenin her yönüyle kritiğini yapmıştır. İlk olarak, Bauman, modern düşüncenin elit, seçkinci bir kavrayışı, ideolojiyi barındırmakta olduğunu düşünür.

Modernite, toplum denilen yapıyı en mükemmel biraradalığa ulaştırmanın hedef olarak belirlene geldiğ mühendisvari algılayıș ve eyleyișlerin ifadesini bulduğu kavrayışlar bütünüdür. $\mathrm{Bu}$ mühendisliğin sosyal alanlarda görünümleri, iş bölümü, teknik rasyonalite, bürokrasi ve ahlak alanına müdahale biçiminde özetlenebilir. $\mathrm{Bu}$ inşa ediş Baumancı düşünümsel terimlerden biriyle ifade edilirse; "adioforizasyon" kavramı çerçevesinde değerlendirilebilir. Adioforizasyon kavramını Bauman alegorik olarak kullandığını belirtir (2002:53). "Tüm yaşam alanların kapsayan, inşa eden bürokratik ve teknik kurallar, düzenlemeler sebebiyle insan eylemlerinin, davranışlarının ahlaki karakterini, niteliğini yitirmesi” (Bauman 2016) durumunu ifade eder. Ahlaki eylemlerin, kişisel karar ve seçimlerden bağımsız önceden modernitenin kendi niteliklerinden ortaya çıkan, belirli, düzenli yönlendirmeleri ile gerçekleştiğini ifade etmektedir. Bauman'a göre; bu durum yine de kişiselliği ortadan kaldıramamaktadır. Buna göre; "davranış kodu ve bir rolün oynanmasına ilişkin seçimlerin kuralları", "gerçek benliği”, istila edebilecek kadar genişletilmiş olamaz. Gerçek benlik, daima gerçek anlamda özgürdür. Bu özgürlük sevincin bununla birlikte hiç de küçük olmayan acının bir nedenidir. Burada salt rol yapmaktan uzak olarak sadece kendimizle baş başayız, gerçekten kendimizizdir (Bauman, 1998:31). Bu durum toplumsal yapıların, statü ve rollerin, modern kültürün beklentilerinin tersine bunların dıșına çıkılabilen düşünce ve doğadan getirilmiş olan ahlaki var oluşun taşıyıcı gücü olan "gerçek benliği” ifade etmektedir.

Modern olarak tabir edilen dönem paradoksları bünyesinde barındırmaktadır. $\mathrm{Bu}$ durum modernitenin oluşturmuş olduğu müphemlikleri ifade etmektedir. Bir taraftan yaşamı rasyonelleştirme isteği ortaya çıkarken diğer yandan bunun tersine sonsuz belirsizlikler var olmaktadir. Modernitenin sonuçlarından biri olarak izah ettiği ve kişilerin güvenebileceği ahlaki doktrinlerin sayısının fazlalığı ve belirsizliği arttırmıştır. Bu müphem durum, merkezlere, otoritelere olan güveni hayli sarsmış ve temelleri modern dönemlerde bulunan "post modernliğin ahlaki krizi" ne yol açmıştır (Bauman, 1998:28). Bu nedenle, bu yeni dönemde eminlik, kesinlik gölgede kalmak durumunda kalmıştır. Bu yeni dönemi karşılayacak yeni bir etik anlayışının ortaya çıkması gerekmektedir. Gündelik yaşam, kişilerin itaat etmek durumunda olduğu birbirleriyle tutarlı ilkelerden oluşan etik buyruklar grubuna, kodlarına indirgenememektedir (Bauman, 1998:33)

Yasa koyuculuk tutkusu yani "aydınlık" kendi ahlaki ilkelerini oluşturarak uluslara yol gösterme ve 'ilkellik'ten, geri kalmışlıktan, kaostan, belirsizlikten, karanlıkta oluş halinden kurtarma gibi çeşitli değişim görevlerini kendine biçmiştir. Ahlak vaizleri, entelektüeller, devlet adamları bu "zorlu" görevi yerine getiren proje adamlığı rolünü üstlenmişlerdir. Temel olarak Thomas Hobbes'dan başlayarak insan doğasının kötü ve belirsiz niteliklere sahip olduğunu benimseyen Aydınlanma dönemi insanları iyi davranışın niteliğini rasyonellik ve rasyonel seçimlerin yapılmasıyla sınırlandırmışlardır(Bauman,1998:40). Bu kavrayışa göre, bir şeyin iyi olduğuna bireyden bağımsız olarak karar veren toplumsal kurumların olması ve kişilerin onların belirledikleri ile eylemlerini sınırlamaları, belirlenme durumunu ortaya çıkarmıştır. Toplumun kurum ve değerleri kişilerin üstünde yer alan yad erkli, dışsal, aşkın bir zorunluluk haline gelmiştir. Bu noktadan hareketle, Kant'ın etik anlayışı buyurgan ve "ödev" temelinde ilerlediği için Bauman tarafından eleştirilmiştir. Bauman (2003:35) 'ın belirttiğine göre, Kant için felsefe, salt teorik bir etkinlik değil, insan aklı adına yasa koyan bir güçtür. Kant, bütün insanları kapsayacak ahlaki ilkeyi bulmayı kendine amaç edinmiştir. Kant böylelikle döneminin tipik yasa koyucu niteliğini taşımaktadır. Bauman'a göre bu durum postmoderniteyi kaçınılmaz olarak oluşturmuştur (Bauman,1998:44):

Düşünsel açıdan ne kadar sağlam olursa olsun, evrensel ilkeleri evrensel davranışın etkili standartları haline getirebilecek (ya da bu nedenle bunu isteyecek), hiç itiraz edilmeyen ve güçlü bir toplumsal kurum yoktur. Bunun yerine, varlığıyla bireyi tatmin edici ve güvenilir hiçbir çıkışı olmayan ahlaki bir belirsizlik durumuna iten birçok kurum ve birçok etik standart vardır. Modern toplumun, evrensel olarak bağlayıcı etik kuralların yasaya benzer bir kodunu ararken geçtiği yolun sonunda, sırtında eylemlerinin sorumluluğuyla birlikte, çelişkili ahlaki talepler, seçenekler ve özlemlerin bombardımanı altında kalan modern birey durmaktadır.

Bauman'a göre modernlik deneyiminden edinmemiz gereken en önemli bilgi modernliğin müphemliği daima ürettiğini düşünmektir. Buna göre (Bauman, 2001:9):

"Toplumsal olarak inşa edilen ve teşvik edilen doğru davranıș kuralları bize öğretilmeden ve biz bunları öğrenmeden önce zaten ahlaki seçim yapma durumunda kalıyoruz... Seçelim ya da seçmeyelim, biz ahlaki bir sorunun içine doğuyor ve yaşam tercihlerimizle ahlaki ikilemler olarak karşılaşıyoruz. Bunun sonucu olarak da, biz, [herhangi bir] sözleşme, çıkar hesabı ya da bir davaya bağlılık yoluyla doğacak herhangi bir somut sorumluluk üstlenmeden çok önce ahlaki sorumluluklar-yani, iyi ile kötü arasında seçim yapma sorumlulukları-taşıyoruz."

\section{Bauman'ın Postmodernite Kavrayışı}

Bauman'ın kendi ifadesiyle (Bauman, 1996), postmodernite, modernitenin öz düşünümselliğidir. Yani bu bağlamda düşünüldüğünde postmodernite, modernitenin kendi başarısızlıklarının, getirilerinin ve sonuçlarının yeniden üzerinden geçilerek düşünülmesi, gözden geçirilmesi homojenlik ve monolitenin yerinin, farklılık ve çokluğun, çoğunluğun kesinlik, belirlilik, ön görülebilirliğin yerinin ise bulanıklık, belirsizlik ve her şeyin olabileceğine bıraktığ durumu ifade etmektedir. Bu doğrultuda "Postmodernlik, kendi orijinal projesinin uygulanamazlığını kabul eden modernliktir. Postmodernlik, kendi imkânsızlığıyla uzlaşaniyi ya da kötü, bununla birlikte yaşamaya kararlı olanmodernliktir" (Bauman, 2003:130) Bu noktada, Bauman'1n 
düşünümselliğini onun postmodernite kavrayıșı temelinde düşünmemiz gerekir.

Bu 'modern kesinlik'ten çıkış ve hep bilinemezcilik ile karşılaşma "postmodern bilgelik" tabiriyle değerlendirilir ve bir kimsenin bir şeyden emin olabilmesinin imkânsızlığı artık su götürmez "gerçek" niteliğindedir. Buna göre hiçbir kimse bu durumdan kaçamaz. Çünkü "Günümüzde güvensizlik, bir uçaktaki yolcuların pilot kabininin boş olduğunu, kaptanın dostane sesinin aslında önceden kaydedilmiş bir mesajın teypten çalınmasından ibaret olduğunu keşfettiklerinde yaşayabilecekleri hisse benzer." (Bauman, 2000:29).

$\mathrm{Bu}$ minvalde, modernitenin içinde yer alan ve ondan hareket eden bütün kuramlar modernitenin sınırları içerisinde çözümlemelerin yapıldığ oluştuğu yapılard1. Kısacası modernite, kendinden menkul ve kendi kendini geçerli kılabilen, kendinin varılabilecek son nokta, en ideal yer olarak ortaya koymakta kültür merkezli kavramsallaştırmaları ile "nesnelliği”" sağlamakta idi. Postmodern söylem, bu durumun tersine kesinliğin, rasyonelliğe verilen sonsuz değerin ve Batı merkezli düşünüş ve kurgulanışın tamamen problematik bir niteliğe sahip olduğunu, modernitenin kendine tasarladığ 1 , biçtiği değerlerin bugünün dünyasında geçerliliğinin söz konusu bile olmadığını ve belki de geçmişin dünyasında da bahsedilen değerlerin, niteliklerin bulunmadığını belirtmektedir. Postmodern tartışmalar batı toplumu, kültürü ve en temelde felsefesi üzerine öz bilinçliliğinin, öz düşünümselliğin ifade edilmesidir (Bauman,1996:143).

$\mathrm{Bu}$ bilinçliliğin ve düşünümselliğin en temel tespitlerinden biri; modernitenin Habermasc1 kavramsallaştırmadan farklı olarak tamamen bitmiş, tükenmiş miadını doldurmuş bir durum, bir deneyimleme olduğudur. Modernite artık her yönüyle irdelenebilecek üzerinde tartışılıp, konuşulması gereken tarihsel bir dönem ve sürece karşılık gelmektedir. $\mathrm{Bu}$ farkındalık postmodernite ile kavramsallaştırılmaktadır (Bauman, 1996:144). Bu yüzden, Bauman için postmodernite, moderniteden bağımsız olarak düşünülemeyecek bir kavram niteliğini taşır. Bauman için postmodernite moderniteden bir kopuş, ayrılış değil onun sonucu, devamı, değişen halidir. Bu motif onun eserlerinde sıklıkla yinelenir.

Bauman için, Modernite öncelikle kesinlikler, belirlilikler çağı niteliğindedir. Modernite anlatısı, Batı merkezinde, Avrupa zemininde ortaya çıkmış ve temellenmiş, kendine yayılacak alanlar bulmaya çalışmıştır. Bu kültür, toplumsal yaşamda da mutlaklıklara, sınırlara, verili gerçekliklere bakarak hegemonik yapılar tesis etmiş, katı hiyerarşiler, dikotomiler oluşturmuştur. "Bat1-Doğu", "Beyaz-Siyah", "Uygar-İlkel”, "Kültür-Doğa”, “Akıllı-Deli” gibi ayrımlar bu konuda verilebilir. $\mathrm{Bu}$ dikotomilerdeki birinci kelimeler "Modernite"nin insan modelini oluştururken diğerleri yani ikinci kelimeler, eski toplumu, eski kültürü yani mükemmellikten uzak olan "ilkel"i örneklendirmekte, izah etmektedir. Postmodernite bu kesinlik, belirlilik ve hiyerarşiye karşı olunan bir durumu ifade etmektedir. Bu dönem kalıcı, ön görülemeyecek bir belirsizlik veya belirsizlikler toplamı, koşulları altında, yaşamaktır. Postmodernliğe atfedilen özellikler; sonsuz olasılıklar, farklılıklar ve belirsizlikler durumu, olmaktadır. Ne ki, postmodernite, bazı kuramcıların düşüncelerinin aksine Bauman için, bir son, bir bitiş, tarihin sonu, niteliğini taşımamaktadır. Tam aksine, yeni bir dönem ve başlangıç niteliğini taşıyabilecek potansiyele sahiptir. Belirsizliğin, farklılığın ve çokluğun bizimle beraber sürekli bir arada olması doğru ve yanlış, iyi ve kötü gibi keskin ayrımların olamayacağı, olmadığı anlamına gelmektedir.

\section{Yasa Koyucular ve Yorumcular}

Bauman, ilgili eserinde, entellektüellik analizine girişmiş ve modernite'yi bir proje olarak anlamlandiran toplumsal ve kültürel yapılardan biri olarak Fransa'daki "Les philosophes" grubunu ele almıştır. "Les philosophes" grubu entelektüelin öncüleri konumundadırlar. $\mathrm{Bu}$ grup, 18.yüzyılın son çeyreğinde Fransa'ya özgül koşullarla ortaya çıkan ve farklı ilgi alanları ve sosyo-ekonomik koşullara sahip kimselerden oluşan modernitenin "aktif ütopya"nın oluşturucuları ve en önemli ajanları özelliklerini taşımaktadırlar. Bauman'ın (1996:33-45), anlatımı ile Les philosophes grubu, Aydınlanma geleneğini bir fikir üretimi, düşüncenin yayılması olarak görmekten ziyade bir eylem pratiğinin bütünlüğü olarak, bir yaşam tarzı, bir yaşam ideolojisi olarak görmüşlerdir. Dolayısıyla "jakoben” politikalar bu grubun uzantıları olarak değerlendirilmektedir.

Avrupa'da 18. yüzyıl ile birlikte toprak mülkiyeti hakları ile idari görevler arasında ilişki, bağlantı kuran Feodal dönem etkisini yavaş yavaş yitirmekte, siyasal erk toprak sahiplerinin elinden çıkmış, aristokrasi rolünü yitirmektedir. Boşalan bu siyasal sınıfın yerine mutlak monark geçmiştir. $\mathrm{Bu}$ geçiş beraberinde feodal tebaalıktan modern devletin yurttaşlığına geçişi getirmektedir. Bauman, bu geçişi ve vatandaşlık sorumluluğunu "bahçe" ve "bahçıvan" metaforuyla ifade etmektedir. Bauman'ın ortaya koyduğu bahçe metaforu modernite ile beraber ortaya çıkmış olan doğa/bahçe yani doğa/kültür dikotomisini açıklayan bir anlatım biçimi niteliğindedir. Bauman için doğa modern zamanların oluşması ile birlikte insan iradesi ve aklına tabi kılınabilecek erekli eylemin, pasif nesnesi konumunda bulunmaktadır. Doğanın kendisi, erekten yoksun, dolayısıyla da efendileri olan insanların enjekte edeceği bir amacı emmeyi bekleyen bir nesne anlamını taşımaktadır. Doğa kavramı kendisini doğuran insanlık kavramının karşıtıdır. Bu nedenle, insanlığın "Holocaust"'ta görüldüğünü belirtmektedir ve ilgili eserinde bu mesele üzerine geniş bir tartışma yürütmektedir. Toplumun düzenlenmesi gereken bir nesne konumuna indirgendiği düşüncesi, holocaust olayında görülmektedir. Dolayısıyla holocaust, modernite içerisinde bir anomali (aykırılık) değil tam tersine modernitenin gelmiş olduğu bir durak, bir aşama, gelinmesi kaçınılmaz olan bir süreç olarak değerlendirilebilecek bir vaka, bir olgu niteliğindedir. Sadece Yahudi olmakla ilgili ve sınırlı bir konu değildir. Buradaki "Yahudilik" bir metafor niteliğini taşımaktadır. Dolayısıyla bu vaka "yerel "değil "evrensel” bir insanlık durumunu ifade etmektedir. Bauman'ın (2007:13-33) belirtmiş olduğu gibi; holocaust, Yahudilere yönelik bir nefretin sonucu, insanın yok etme dürtüsünün bir uzantısı, insanın bastırılamayan "doğal" bir eğilimi, toplumsal yapıdaki bozulmanın bir sonucu, esasen mantıkdışı etkenleri baskı altına alamayan modernleşme, duygusal ve saldırgan dürtülere boyun eğdiremeyen uygarlaşma baskıları, çarpık ve sonuçta yeterli miktarda motivasyon üretemeyen toplumsallaşma ve diğer sayılamayacak kadar çok bahanelerle bu olay, bu olgu kavranamaz. Bu doğrultuda; Holocaust, modern uygarlığın bir görünümü, doğal, normal, olağan bir ürünü, tarihsel eğilimi olarak kavranmalıdır. Bauman (2007:33) için Holocaust, modernlik evinin meşru 
bir sakinidir. Max Weber'in kuramsallaștırdığı rasyonelleșme ve bürokrasinin sorunsuz bir biçiminde ilerleyen her şeyin görev duygusu ile belirlendiğini yaşam planı ve etik anlayışının sonuçlarını incelemek bizim holocaust ' $u$ daha da iyi anlamamıza katkıda bulunur. Holocaust, modern bürokrasi ve onun temsil etmiş olduğu araçsal mantıklılık kültürünün bir sonucudur. Bürokratik örgütlenme ile kişilerin yüzleri silinmektedir ve yerine getirilecek görev için her şey yapılabilir. Bauman (2007:215) bu durumu şöyle izah eder:

"Otoriter bürokratik sistemin en dikkat çekici özelliklerden biri de kişinin yaptığı eylemlerin. Ahlaksal yönden garabetinin keşfedilme olasılığının azalması ve keşfedildiğinde de acılı bir ikileme dönüşmesidir. Bürokrasi içinde görevlendirilmiş bir kişinin ahlaksal kaygıları eylem amaçlarının kötü yanları üzerinde yoğunlaşmaktan alıkonulur. Bunlar zorla başka yöne -yapılacak işe ve işin yapılışındaki kusursuzluğa- kaydırılır. Eylemin hedeflerinin başından neler geçtiği ya da hissettiği o denli önemli değildir. Ama üstlerinin görevliden yapması istediği şeyin ne denli şık ve ustalıkla yerine getirildiği önemlidir. Ve üsttekiler bu konuda en yetkin ve doğal otoritedir."

Bürokratik örgütlenme neticesinde iş parçalara ayrılmakta, görev için kullanabilecek şiddet yetkisi sorgulanamayacak denli ortadan kalkmakta, eylem sonucunda doğacak sorumluluk işin parçalılığı sebebiyle hiç kimse tarafından alınamamaktadır. Bürokratik örgütlenmelerde sorumluluk ve yüzler silinmektedir (Bauman, 2007:219):

Sürekli ve her yerde, her zaman var olan sorumluluk kaymasının genel sonucu bir yüzer-gezer sorumluluktur; böyle bir durumda örgütün her üyesi bir başkasının emrinde olduğuna inanır ve sorulduğunda böyle söyler; ama sorumluluğu taşıyan kişi diye gösterilen üyeler de sorumluluğu yine bir başkasına atar. Örgütün tümüyle bir sorumluluk silme aracı olduğu söylenebilir.

Farklı olandan hoşlanmama yani "heterofobi" tarihin her döneminde görülmektedir. Fakat modern çağın, diğer çağlardan farkı bu farklılıktan hoşlanmamanın yerini "yakıcı 1rkçılığa" bırakmasıdır. Modern çağın öncesinden farkı, bu dışlama durumlarının kendine özgü birtakım araçlar ve yöntemlerle katliama ve soykırıma dönüşmesidir. Bu durum modernizmin özgünlüğünü ortaya koyan sosyal mühendislik çalışmalarında ifadesini bulur. Toplumsal ve kültürel sınırların ortaya konması ve düzenleme "irkçılık" olgusunda kendini bulur. $\mathrm{Bu}$ doğrultuda, ırkçılık, layık olduğu yere ancak mükemmel toplum için yapılan düzenlemenin koşullarında ve bu düzenlemeyi planlı ve tutarlı çabalarla modern devlette bulabilmektedir (Bauman, 2007:97). Mükemmel bir düzen ütopyasından hareket eden ve yeni bir "ahlak" yaratma peşinde olan modern devlete göre, bu kültürün kalıplarına uymayacak nitelikteki bahçenin zararlılarını yani daha yaygın bir tanımla "öteki”leri merkezden uzaklaştırmak, gerekirse "yok etmek" gerekmektedir.

$\mathrm{Bu}$ ütopyanın gerçekleştirici ajanlarından biri devlet örgütlenmesi ise diğeri de pozitivist bilim anlayışını olmaktadır. Modern devlet ve onun amaçları doğrultusundaki araçlardan biri bilimdir. Özellikle Holocaust hususunda, tıp bilimi ve teknik bilimler önem arz etmektedir. Değerlerden bağımsız olarak var olan bilim, bürokratik belirlenimler ve mühendislik çabaları ile bir korku makinesine dönmektedir. Bauman'ın ifadesi ile Holocaust bilimsel bir çaba, bilimsel bir idealiteyi teșkil etmektedir. Böyle bir durumda evrensel ahlak standartları adına "adioforik" bir karaktere büründürülen ve bürünen toplum," öteki için” değil "ötekine rağmen" ve giderek “ötekinin olmadığı” bir alana dönüşür.

\section{5. Özgürlük}

Bauman'a göre, modernitenin, kendisinden önce gelen, ilksel veya geleneksel topluma nazaran kendini özgür bireyi yaratan, var eden ve özgürlüğün son noktasına ulaştığını vurgulayan bir toplumun yaratıcısı olarak görmesi önemli problematiklerden birini oluşturmaktadır. Özgürlügün ulaşmış olduğu son noktanın modernite ile tesis olduğu diskuru ve sosyal bilimlerin bu fikriyatın çerçevesinde modernite ile biçimlendirilmesi, sosyal bilimleri "özgürlüksüzlüğün bilimleri” haline gelmiştir. Çünkü sosyal bilimler, ana akım pozitivizmin etkisi altında kalarak özgürlük kavramını, insanın özüne, "doğasına" ait bir değer olarak algılamıştır (Baumann, 1997:11). Bauman, bu egemen söyleme karşı özgürlüğün "doğal” bir kavram olmaktan ziyade tarihsel ve toplumsal koşullar ve nedenlerle ele alınması gereken bir kavram olduğunu belirtmektedir. Bauman, modern toplumlardaki özgürlük kavrayışını diğer toplumlardan ayıran durumun onun daha "hakiki" bir özgürlük olmasından kaynaklanmadığını, tamtersine bürünülen yeni biçimler, toplumsal kurumlar ve yeni toplumsal terimlerin böyle bir düşünceye yol açtığını savunmaktadır. Bauman, bu çerçevede özgürlüğün, modern yaşam alanlarında ve toplumsal, kültürel alanlarda yaşamanın temeli olduğunu ve her şeyin aslında pazar ve piyasa koşulları tarafından belirlendiğini ifade eder. Bauman, özgürlüğün, aslında, modernitenin yaratmış olduğu müphemliklerden biri olduğunu ve özgürlük kavramının da erişim koşullarının eşitsizliğiyle şekillendiğini ifade etmektedir. Yenidünya düzeninde de aynı şekilde farklı kategorilerle eşitsizlikler sürmektedir. Bauman, bu duruma örnek olarak Kuzey-Güney veya Aylaklar- Gezginler (Turistler) kategorilerini vermektedir. M.Foucault'un J.Bentham'dan yola çıkarak oluşturduğu "panoptikon" ve "panoptical kurumlardan hareket ederek gözleyen ve gözlenen arasındaki eşitsizliğinin modern kapitalist toplumda nasıl kurumsal hale geldiği hususuna Bauman da çözümlemelerinde asli bir yer vermektedir. $\mathrm{Bu}$ durumun “özgür olmak demek, başkalarını özgürlüksüz bırakma yetkisine sahip olmak demek”tir tespitiyle ifade edildiğini belirtmektedir (Bauman, 1997:18). Panoptikon düzeneğinde, gözetleyen hâkimler, sistemin uzmanları ile gözetlenen mahkûmlar yani eşitsizliğin diğer tarafında yer alanlar bulunmaktadır. $\mathrm{Bu}$ gözetimin herkes farkındadır ve kişiler kendilerini buna göre kurarlar. Modern kapitalizmin ürettiği özgürlük anlayışı “öz denetim” ile sağlanır (Bauman, 1997:64):

Kapitalizm adını verdiğimiz, araç-amaç hesaplarının sınırlı ve kısıtlı kaynaklar arasında seçim yapma sorununa uygulanmasıyla bir toplumun süreğen ve sağlam ekonomik işlevlerinin yani insan gereksinimlerinin doğa ve diğer insanlarla değiş tokuş yoluyla karşılanmasının yerine getirildiği bir durumdu. Ama seçim ve araç-amaç hesabı, yani, güdülenen, amaçlı, akılla yönlendirilen davranış modern toplumun özgürlük tanımına ait temel özelliklerdir. Kapitalizm, tanımıyla, özgürlüğe kesin olmasa bile büyük bir toplumsal yaşama alanı açar; insan gereksinimlerinin tatminini amaçlayan malların üretimi ve dağılımı. Kapitalist ekonomi biçiminde özgürlük -en azından ekonomik özgürlük 
-gelişebilir. Dahası özgürlük bir zorunluluğa dönüşür. Çünkü o olmadan ekonomik etkinlik amacına ulaşmaz.

Özgürlük, modern kapitalist tüketim toplumunda; tüketicilik çerçevesinde değerlendirilmekte ve böylelikle sınırlar tüketici olup olmamakla belirlenmektedir. Ve böylece rekabet simgesel rekabete kaymakta ve böyle bir durum da özgürlük zorunluluk haline gelmektedir. Tüketim toplumu içerisinde yer alan ve seslerini duyuramayan insanlar bulunmaktadır. $\mathrm{Bu}$ insanlar yoksulluk tanımı çerçevesinde değerlendirilirler. Sabit işleri ve gelirleri yoktur. Geçici, düzensiz, yasal hakları olmayan işlerde çalışmak durumundadırlar. Onlara bağımlı, bakmakla yükümlü oldukları çok sayıda insan bulunmaktadır. Yanlış ten rengine sahiptirler ve sermayenin terk ettiği bölgelerde, mekânlarda yaşamaktadırlar. Bu doğrultuda onlar "kusurlu tüketiciler" olarak değerlendirilmektedirler ve bu grupta yer alan insanlar "doğal" olarak sahip oldukları özgürlüklerini doğru kullanamamaları, neyin kendileri için iyi olup olmadı $\breve{g}_{1}$ ve özgürlüklerini nasıl kullanmaları gerektiğini bilenlerin direktiflerine uymaları gerekmektedir. Gözlenmeleri, düzeltilmeleri, itaatsizlik, uyumsuzluk durumunda cezalandırılmaları, özgürlüğün zorunluluk olduğunun görünümlerindendir (Bauman, 1997:116).

\section{6. Üretimden Tüketime Farklı Toplumsal Yapılanmalar}

Bauman'ın yorumuna göre, modernite'yi daha çok üretim ve çalışma simgelerken, postmoderniteyi tüketim toplumu simgelemektedir. Modern sanayi kurulmasının ardından kendine özgü bir çalışma etiğini geliștirmiştir. Bauman'ın ifadeleriyle bu etik biçimi, çalışmanın başı başına bir değer, asil ve asalet verici bir etkinlik olduğunu bildiren yargılar grubudur (Bauman, 1999:13-14):

"Çalışma etiği, sanayileşmenin erken safhalarında ve onun dolambaçlı modernite ve modernleşme" yolundaki değişimlerinde Avrupa bilincini kapladığından beri politikacılara, düşünürlere ve benzer türdeki vaizlere, kurmak niyetinde oldukları yeni cesur dünya karşısında en büyük engel olarak gördükleri yaygın alışkanlığın ne yapıp edip kökünü kazıma gayretlerinde bir bahane, ya da çok açık bir çağrı hizmeti görmüştür: Kökü kazınmak istenen bu alışkanlık, fabrika istihdamının sözüm ona nimetlerinden eğer mümkünse sakınmaya ve ustabaşı, saat ve makine tarafından ayarlanan yaşam ritmine uslu uslu itaate direnmeye yönelik sözde yaygın eğilimdi."

$\mathrm{Bu}$ oluşturulan çalışma anlayışı ile birlikte "panopticon kurumlar"2 kendilerini oluşturmuşlardır. Okullarda eğitmenler, kiliselerde din adamları ve neredeyse geleneksel olarak bir uyum halinde olan aydınlar tarafından aracılığı yapılan bu etik anlayışı çalışmayı yalnızca asgari, geçimlik bir olgu olarak değil de başlı başına bir değer, en yüce eylem, kamusal yarara, ortak iyiye hizmet ederek ulaşılabilecek tinsel bir gelişim, bir anlamda kutsallıkla eşdeğer bir olgu olarak görmektedir (Bauman, 1999:13-15). Modern endüstriyel toplumlarda işe yapılan vurgu ve herkesin çalışmaya çalıştırılması ve işçileştirilmesi toplumun

\footnotetext{
${ }^{2}$ Yeni dönemde yani modern dönemde, toplumsal yapı, panopticon yani total kurumlardaki dönüşümle simgelenmektedir. Bauman'ın, modern dönemin eseri olarak ifade ettiği bu kurumsal yapılanmalar, tek ve belirli merkezden yönlendirilen kontrol, denetim ve disiplinin simgeleri, taşıyıcıları olmaktadır. Bu kurumlardan bazıları; akıl hastaneleri, ceza ve islah evleri, okullar, fabrikalar, bürokratik örgütlenmeler ve ordu gibi kurumlardır.
}

eksikliğini ve problemleri giderici, ve kurtarıcı bir şey olarak görülmekteydi. Bu ethosa göre, modernitenin her iki ayağ tarafından yani hem kapitalizm hem de komünizm tarafindan çalışmak kişisel ve toplumsal sorunları aynı anda çözüm olabileceği düşünülen bir erdem ve tinsel arınma olarak insanın olmazsa olması ve insanı var kılan bir olgu olarak değerlendirilmekteydi. Marx'ınçalışmaya verdiği önem ve onun insanı diğer varlıklardan ayıran unsurun çalışma olduğunu düşünmesi ve toplumu bir atölyeye benzeterek çalışmayı vurgulan Saint Simon'u kendilerinin önceli olarak sunması Bauman tarafindan eleştirilmiştir. Bu dönemin şiarı, Bauman'a göre "çalışmayan aç kalır” biçimindedir.

Endüstri toplumlarında çalışma ve iş, meslek bir kişinin tanımlayıcı, kimliksel unsurlarından olmaktadır. Çalışma hayatın merkezinde ve diğer unsurları etkileyen, belirleyen ve planlayan bir yapı niteliğindedir. İş yerleri ve bürokratik organizasyonlar sosyalleşmelerin yani bir anlamda toplumsal bütünleşmenin, kültürleşmenin alanları, mekânları idi. Kurallara itaat, disiplin gibi alışkanlıklar ve sosyal kişilikler buralarda şekillenmekte modernist kültürün unsurları bu mekânlarda yönünü ve biçimini belirlemekteydi. Panopticon kurumlarının uzantıları niteliğindeki toplumun "en temel birimi" aile, ailenin "lideri" olan erkeğin iş yaşamında edindiği kurallar ve disiplinin aile içerisinde uygulanmasının ajanı olarak ataerkil değerleri ve yapıları kadınlar ve çocuklara aktarılmaktadır.

Günümüze gelinceye değin, 20.yüzyılın ilk zamanlarından itibaren daha iyi çalışma, ethosu yerini daha çok kazanmak, paralara para katabilmekti. Bu dönemin temel cümlesi teşvik, ayartılma ve tüketim şeklinde sıralanmaktadır (Bauman,1999:39). Total kurumlar, insanları geleneksel, rutin bir biçimde davranmaları konusunda "kültürel haçlı seferleri" düzenlemekte idi. Ama çağın tüketim toplumunda bu temeller sarsılmakta ve rutinin olmaması ve sürekli değişiklik, alışkanlık ve tutkuların anlık olması, hiçbir şeyin mutlak bir biçimde benimsenemez, bağlanılamaz bir duruma geldiğine işaret etmektedir. Bu dönemde geçerli olan tek şey her türlü bağlanmanın uçuculuk ve geçiciliğidir. Her türlü tüketimin zaman alması tüketim toplumunu var kılanlar için bir felaket ve mal satıcıları için bir risk özelliğini ihtiva eder (Bauman, 2007:41-42). Böylelikle artık çalışma etiğinin yerini "tüketim etiği”" almaktaydı. Bir önceki dönemin aksine bu dönemde bütünsellik ve toplumsallık önem arz etmektedir. Bu dönemin ayırt edici özelliği” tercih" özelliğidir. Var olan toplum bir şimdi toplumudur, gündelik toplumdur. Bekleyen, sabreden bir toplumdan ziyade isteyen, talep eden bir toplumdur. Artık toplum yapısı etikten estetiğe doğru bir geçiştir. Toplum etik önermeler ve buyurularla değil de estetik içeriklerle ayakta duran kredi kartları toplumu olmaktadır (Bauman, 1999:55).

İstihdam politikaları bu yeni dönemde değişime uğramıştır. Üretim toplumunda politikalar, tam istihdam çerçevesinde gelişmekte idi. Bu durum sabit bir iş ve meslek demekti. Kişiler ve toplum için iş ve meslek sahibi olmak ve çalışmak ortak iyinin ve arzunun peşinden gitmek demekti. Günümüzde, istihdam sabit ve belirli alanlarda emekliliğe kadar çalışmaktan ziyade değişken, süreksiz, her an farklılaşabilecek bir riziko içerisinde çalışmak demek ola "esnek istihdam"dır. Kişi ne iş olsa yapar. Üretim toplumunda çalışmayan, tembellik yapan, ortak iyi için çaba göstermeyen kimse "yoksul" olarak değerlendirmekte iken tüketim toplumunda" yeterince tüketemeyen" kişiler "yoksul" 
olarak değerlendirilecek hale gelmektedir. Bu toplum yapısı içerisinde yoksulların hissetmiş olduğu şey bu toplumun vaat etmiş olduğu tüm nesnelerden mahrum olma, eksik kalma duygusudur. Tabiî ki yoksul olsun olmasın, tüketim toplumum üyeleri için tam bir tatminin, doyumun sağlanması o toplumun temelini sarsabileceği için bu durum sürekli dikkate alınır ve tüketim toplumu kendini yeniden kurar.

Yeni dönemin tüketim toplumunda yoksulluk kategorisini oluşturanlar genişlemişlerdir. Bauman, işçi sınıfi ve alt sınıf tabirlerinin artık etkinliğini yitirdiklerini belirtmektedir. "sınıf dışı veya altı" kavramının günümüz ikili kategorisini daha net bir biçimde açıkladığını ifade etmektedir (Bauman,1999:99) . Bu kategoriyi oluşturanlar oldukça farklı kimseler ve kimliklerden gelmektedir. Bir homojenlikten bahsedebilmemiz mümkün gözükmemektedir. Bu kimselere örnek vermek gerekirse; devletten yardım alanlar, dilenciler, alkol bağımlıları, yasa dışı göçmenler, çete üyeleri v.b. verilebilir. Onlar toplum nazarında hep korkuyu ve tehlikeyi karşılamaktadır. Böylelikle Bauman toplumdaki iki kesimi yararlı olan ve tehlikeli olan şeklinde ikili bir şekilde değerlendirmektedir. Toplumdaki tabakalaşma sebebiyle Bauman sınıf altına giren kimselerin sayılarının artmaları ile paralel olarak sefalet ve suç oranında artışların söz konusu olduğunu belirtmektedir. Bauman, bu bağlamda suçu tüketim toplumu içerisinde bir beklenmedik, bir anomali saymamaktadır onun beklenen ve doğal bir sonuç olduğunu ifade etmektedir (Bauman, $1999: 111)^{3}$. Talihli sınıfların gözünde yoksullar çalışma etiğini dikkate almadıkları için bu durumdalardır ve tehlikeli bir varlık haline gelmişlerdir. Sefaletin, suçluluk olgusu ile birleşmesi talihli sınıfların yoksullara olan geleneksel etik sorumluluklarını da ortadan kaldırmaktadır. Buna karşın ahlaki dürtüler tamamen ortadan kalkmamakta bir kenarda birikerek "hayırseverlik karnavalları" ile yüzeye çıkmaktadır. Yoksula yardımlar bu çerçevede anlamlandırılan eylemler halinde karşımıza çıkmaktadır.

Bauman, modernitenin tarihselliği ile ilişkilendirdiği panopticon kurumların bu yeni dönemde, Foucault'dan farklı olarak, ortadan kalkma, erime durumu ile karşı karşıya olduğunu belirtmektedir. Bilginin ve iktidarın merkezsizleşmesi durumu, özneleri inşa eden bu mekanizmaların ortadan kakmasına vesile olmaktadır. Yeni toplumsal yapılanma içerisinde tüketim toplumunun ethosu sebebiyle yönlendirmeler, teşvikler tüketim doğrultusunda yapılmakta bu yönlendirmenin tesiri altında kalmayanlar varlık olarak kabul edilmemekte, disipline bile edilmeye çalışılmadan yok olanlar hanesine yazılarak gettolara ve hapishanelere yerleştirilmektedir. Gören gözlerin uzağına itilmektedirler.

\section{Küreselleşme}

Bauman, eserlerinde, tarihsel süreç içerisinde oluşumundan zirvesine modernitenin durumu ortaya koymaya çalışmakla birlikte, dünyadaki çağcıl gelişmelerle birlikte kavramsallaştırılan Küreselleşme dönemiyle ilgili yoğun incelemeler ve değerlendirmeler yapmaktadır. Postmodern etiğin, küresel çağdaki anlamını ve küreselleşmenin doğurduğu sonuçları gözlemleyip, değerlendirmekte, "çıkışı" aramaya çalışmaktadır. Şanslı sınıflar/sınıf altılar veya dışılar, aylaklar ve turistler, sermaye

3 Marx'ın kuramındaki burjuva ve proleter sınıflarının yerini Bauman için Postmodern çağda "yoksullar ve şanslılar" almaktadır. ve ulus -devlet, zaman ve mekân gibi dikotomiler küreselleşmenin toplumsal sonuçlarıdır (Bauman, 1999).

Modern devlet ulus-devlet ile mekânı yeniden inşa etmiş, tek merkezden kontrol ve yönetim tesis edilmiştir. Modern öncesi, kaotik olan, çeşitliliği ifade eden yapının yerini Modern dönemle birlikte "düzen" ve türdeş bir yapı almıştır. Bu tek merkez, etik dâhil olmak üzere yaşamın bütün unsur ve görünümleri baskı altında tutmakta, biçimlendirmektedir. Küreselleşme dönemi ile birlikte bu tek merkezliliğin komutası kırılmaya başlamıștır ve şeyler -ki bu şeylerden en büyüğü olan dünya- ellerden kaçmak üzeredir. Artık varlığından ve mutlaklığından emin olabileceğimiz bir merkez kalmamaktadır. Bu durumun birinci nedeni mekânı yok eden ve zamanın anlamının kalmadığı teknolojidir. Artık merkezin dışında duruma müdahale etmek isteyen yerellikler seslerini duyurmaya çalışmaktadırlar. Günümüzde geleneksel topluluk grupları enformasyon ve bilgi akışının hızının getirmiş olduğu imkânlar ile diğer topluluklar arasındaki iletişim kopuklukları ve aksaklıklarını aşmaktadır. Bu durumun doğrudan sonucu kimliklerin, kolektif temsillerin erimesidir. Topluluk içi iletişim ile topluluklar arası iletişimlerin aynı anda gerçekleşir hale gelmesi küçük birimleri birbirine daha az ihtiyaç duyar hale getirmektedir. İnsanların farklı iletişim ve bilgi akışlarını kullanmaya başlaması ile birlikte onu yönlendiren, sabitleyen ve anlamlandıran referanslar azalmakta veya kaybolmaktadır. $\mathrm{Bu}$ durum aynı zamanda "panoptikon" ve modern devlet anlayışının çözülmesi ve çöküşü ile sonuçlanmaktadır. Modern devletin iletişimi belirleyen yasaları ve sansürleri bu yeni dönemde tek yönlü bilgi bombardımanına yol açmış, ancak farklı iletişim kanalları ile alternatif enformasyon ve yeni mekanizmaların mevcudiyeti ile bu monolitik süreç sonlanmıştır. Modern devletin kurguladığı anlamlar ve kodlar alıcısına ulaşamamaktadır. İnsanlar geleneksel yapılardan ve modernitenin referanslarından kurtularak sorunlu özgürlüklerinin peşinde yol almaktadırlar. Kiliseler, siyasi partiler ve akademik kurumlar inandırıcılık ve otoritelerini önemli oranda yitirmişlerdir. İnsanlar bu dönemde paralel söylemler, birlikteliklerle kendilerini ve kimliklerini sürekli kurmaktadırlar. $\mathrm{Bu}$ durum bütün gruplar ve insanlar için mutlak eşitlik yaratmamakta tam aksine farklı biçimlerde eşitsizlikler ortaya çıkmaktadır. İnsanlar iletişim kanallarına ulaşırken sağlanan eşitlikler mekânsal özerklikler hususunda sağlanamamakta, sermayeyi ellerinde tutabilecek olan uzmanlar yerelliklerinden koparak dünyaya istedikleri yerlere gidebilecek gezginler olarak bu özerkliği edinebilirken, diğer kesim olan yereller, aylaklar üzerinde yaşadıkları mekânın, toprağın ayakları altından kaydığını hissetmektedir. Bu durum bizim küreselleşmenin oluşturucu ikinci nedeni olan sermayenin sınır tanımayan dolaşımı üzerinde düşünmemizi sağlamaktadır. Enformasyonun ulaşmış olduğu sürat ve teknolojinin gelişkinlik süreci ya da bir diğer ifade ile zaman ve mekânın sıkışması sermayeyi daha önceki dönemlere kıyasla daha "bağımsız" bir hale getirmiştir. Sermayenin dolaşımı ulus devletin sınırlarını zorlamaktadır. Anonim bir güç halindeki sermaye ulus-devletlerin politikalarını yeniden gözden geçirmelerine neden olmakta hatta onları her bakımdan sınırlandırmaktadır. Bu yeniçağın ethosu mutlak bir düzensizlik ve kontrol edilemezliktir. $\mathrm{Bu}$ durum aynı zamanda ulus-devletlerin içinde bulundukları meşruiyet krizini oluşturmaktadır. Devlet, bir önceki dönemde asli görevlerinden ekonomik, güvenlik ve kültürel hegemonya görevlerinden sıyrılmıştır. 
Sermayenin kazandığı bu özerklik ve yer tanımazlık beraberinde tüketim toplumu kavrayıșını getirmektedir. Tüketim toplumunda toplum içerisinde tabakalaşma ve katmanlaşmanın sürmekte olduğu, bunu belirleyenin de hareket özgürlüğü ve serbestliğinin sağlanıp sağlanamaması olduğu belirlenmektedir. Bu durum mekâna bağlı olan veya değişken mekânlarda söz sahibi olabilen olarak da okunabilecek olan aşağıdakiler ve yukarıdakiler kategorileriyle anlatılmaktadır. Bu ikili ayrım günümüz dünyasında sınırları daha da arttırmaktadır. Kimisi sitelerin güvenlik duvarları ardında yaşarken aşağıda kalanlar, belki de hep kalmak durumunda olanlar tecrit halinde, getto yerlerde yaşamaya çalışmaktadırlar. Bu durum, hareketlilik, iletişim kurmak ve sınırları aşmak gibi amaçlara ulaşılmasını imkânsızlaştırmakta aksine öteki korkusu, yabancı korkusu ile ş̧ekillenerek korkular yeniden üretilmekte diyalog imkânsızlaşmaktadır. Küresel düzeyde hareket imkânına sahip birinci dünya ve kuzey ülkeleri için mekânın kısıtlayıcı niteliği kalmamış hem gerçek dünyada hem de sanal dünyada vizenin geçiş izninin ortadan kalkıp pasaportla seyahat edebilme imkânı ile yollar kolaylıkla geçilmektedir. Bu kişiler Bauman'ın metaforik anlatımı ile "turistler" olarak tabir edilmektedir. Diğer kimseler için yani ikinci dünyada gerçek mekân giderek daralmaktadır. Bu daralma beraberinde zamanın akışını da dondurmaktadır. Birinci dünya insanı için zaman çok önemlidir. Çünkü onlar hep meşguldürler ve zamanla yarışmak zorundadırlar. Yüklü dosyalar onları beklemekte ve sermayenin durumu piyasalarda anlık değişimler söz konusu olmaktadır. İkinci dünyanın insanları için ise durum farklılaşmaktadır, bu insanlar sabit mekân içerisinde yaşamaktadırlar. Zamanları boldur ve bu zaman bolluğu karşısında onlar ezilmektedirler. Birincilerin tersine ikincilerin seyahat ve hareket özgürlüğü ya çok dar veya hiç yoktur. Onlar gizli, çoğu zaman da yasa dışı yollarla hareket edebilmekteler şansları varsa yeni bir yaşama başlamaktalar diğer yandan talihsiz olanlar ya yolculukları sırasında yaşamlarını kaybetmekte veya vardıkları "vaatler ülkeleri”"nde tutuklanıp sınır dışı edilmekteler veya bir diğer ihtimal kaçak olarak yaşamlarını sürdürmektedirler. Turist olanın en büyük kâbusu aylaklık statüsüne inmektir. Bu durum sürekli olarak risk oluşturur. Aylakların varlığ 1 ve görünümleri turistleri endişelendirmekte ve rahatsız etmektedir. Bunun nedeni Bauman'a göre, aylağın ne olduğunu değil, turistin ne olabileceğini göstermesidir (Bauman, 2000:145). Aylakların olmadığı bir dünya, turistlerin ütopyasını oluşturmaktadır. Buna rağmen turistler varlıklarını aylaklara borçlu olduklarını bilirler ve aylağın olmadığı bir yerde onların icat edilmesi turistlerin kendilerini inşa etmesi için elzem bir durumdur. Aylaklık ve turistlik günümüzde istihdam ve sermaye hareketlerinde yaygın olarak Bauman tarafindan gözlenmekte ve kavramsallaştırılmaktadır. Bauman bu ikili ayrımı, yani gerek aylakların varlığını gerekse de turistlerin bu durumdan kaynaklı rahatsızlığını çağcıl yoksulluğun ifadelendirilmesi olarak düşünmekte ve bu ayrımın modernitenin çalışma etiğinin sonuna işaret ettiğini belirtmektedir.

\section{Yeniden Başlangıcın Olanağı ya da Postmodern Etiğin İmkânı}

Bauman, günümüz dünyasında mevcut olan sorunlar karşısında modernite döneminde hâkim olan "büyük anlatılardan" uzak durmaya çalışmakta, tünelin ucundaki ışı̆̆ etik temelindeki tartışmalarla bulmaya, takip etmeye çalışmaktadır. Postmodern etiği kavramsallaștırmaya çalışırken postmodernite'nin etik boyutunun vurgulanması ve dikkate alınmasını önermektedir. Bauman, modernitenin etik anlayışının olup olmadığını sorarak etik tartışmalara başlamaktadır. Modernite, ahlaki durumu ve sorumluluğu bireylerden bağımsız, hatta aşkın kilise ve devlet tarafından alıkoymakta, yad erkli, dış erkli bir niteliğe sahip ahlaki sorumluluk ve etik anlayışını gündeme getirmektedir. Devletin ve dini kurumsal yapıların otoritesi artık bugünün insanları için bir anlam ifade etmemektedir. Günümüz koşullarında her iki yapı da kriz içerisinde yer almaktadır. Bauman, Kantçı anlamda, mutlak ve evrensel kodların bulunmadığını bizlere bildirmektedir. Dolayısıyla modernitenin olmayan etik anlayışının dışında bütün insanları kapsayabilecek ve toplumsal, kurgusal ayrımları aşındıracak yeni bir etiğin arayışı içerisine girmektedir. Bu doğrultuda kendisine yol gösteren, ipucu sağlayan yaklaşımı fenomenolojik felsefeden gelen ve bu felsefenin kurucusu Husserl'in öğrencisi olan Levinas'ta bulmaktadır. Levinas'ın temel hareket noktası, kendisinden önceki fenomonolojik tartışmalardaki ve varoluşçu felsefe tartışmalarında ana problem olan Aşkın öznellikten kendi etiğini oluşturduğu özneler arasına geçiştir. Levinas için etik ontolojiden yani varlık felsefesinden önce gelmekte idi (Sayın, 2002:43-64). $\mathrm{Bu}$ doğrultuda Levinas öteki temelli, özgeci bir etik anlayışına sahiptir. Sartre'ın ötekinin "cehennemliği”" ve "gölge" benliğinden farklı olarak "ben öteki içindir" kavrayışına sahiptir.

Bütün bir insanlık tarihinin, insan yaşamının ve kültürlerin var olabilmesinde ölüm olgusunun etki etmekte olduğu teması, özellikle postmodern literatürün belli başı tartışmalarından birini oluşturmaktadır. Buna göre insan yaşamına anlam veren ve kesin olarak bilebileceğimiz tek şey insanın ölümlü bir varlık olduğudur. Bauman'ı Levinas'ın ölüm konusundaki görüşleri ve bunun sonucunda etiğini oluşturması etkilemiş ve zihnini açmıştır. Levinas'a göre ölüm deneyimi ertelenemez, reddedilemez mutlak “ötekimizdir”. Levinas’a göre ölüm deneyimi, mevcut radikalliği içerisinde "tikel" olabilen durumsallığı retorize etmektedir. Hiçbir varlık bir başka varlığın ölüm anındaki durumunu hissedemez, bilemez, açıklayamaz. Ölümün sadece ölümün karşıladığı varlığa ait olması durumu, radikal özgürlük açılımını da kavramsallaştırmamıza yardımcı olmaktadır. Ölümün hiçbir varlı̆ga ait olmaması, ölüm deneyimini özgürlük miti açısından dönüştürebilmemize olanak tanımaktadır (Levinas, 2005:22-25). Yani ölüm herkese aittir ve benliğin sağlanması "özgürlüğün" sağlanması ötekinin sorumluluğunu almayı ifade eden etik anlayışı ile mümkün olmaktadır. Bir kişinin kendisine "ben" diyebilmek için ötekinin üzerine düşmeliyim, ötekine karşılıksız ve koşulsuz sorumluluk taşımalıyım. Ben olabilmek ötekine duyduğum sorumlulukla mümkün olmaktadır. Sorumluluk evrensel akıl, kategorik buyruk ile gelmez. O dış erkli bir sorumluluk değil, kişinin içinden gelen ve yüz eğretilemesiyle ifade edilen bir durumdur. Sorumluluk ötekinin yüzünde kişiyi kendisine çeker. Bu sorumluluk ile özne olunabilmektedir. Öznellik ötekinin sorumluluğunun alınmasıyla kazanılmış bir şeydir. Levinas'ın etik kavrayışına göre modernitenin "etiği" olan hukuk etikten tamamen farklı bir düzlemdedir ve farklı zamansallıklar söz konusu olmaktadır. Etik var olandan önce gelmektedir. Var olanın şiddet dolu biçimlendirmelerinden, öteki için, bir başkası için alınan gizemli sorumluluğun 
alınması ile ontolojiden etiğe geçiş hali görülmektedir (Çırakman, 2000:180-185). Levinas'ın etik düşüncesi iki kişi arasında gerçekleşen bir "ahlak sahnesi" içerisinde sorumluluk alınmasıdır Levinas'ın ahlaki sorumluluk asimetrik, karşılıksız yapılan eylem veya eylemler bütünüdür. İki kişi arasındaki ilişkilerin dışındaki mesela üçüncü kişiyle olan ilişkiler söz konusuysa etik ilişkiden farklı olarak hukuk ilişkisinden bahsedilmektedir. Kişinin kendini öteki için feda edebilmesi, koşulsuz sorumluluk alabilmesi ancak mikro düzeyde olabilmektedir. Levinasçı anlamda ve çerçevede etiğin makro boyutu yani "adalet" oluşturma pek mümkün gözükmemektedir. Bauman Levinas'ın bırakmış olduğu bu noktadan hareket ederek etiği makro boyuta, toplumsal boyuta, adalete taşımak istemiş, "postmodern etiği" bu doğrultuda oluşturmaya çalışmıştır.

Bauman, etik arayışı içerisinde Hans Jonas'ın oluşturduğu etik düşüncesini de önemser. Bauman, Jonas'ın yakın çağ ve teknolojik problem, istila sorunsallarını ele alan etik kavrayışını gözden geçirmiştir. Bugünün dünyasında teknoloji eyleyebileceğimiz her şey yüz yüze etkileşimin bir aradalığın ötesinde, uzak mekânları ve insanları etkileyebilmektedir. $\mathrm{Bu}$ etkiler tahmin edilenin ötesinde derin, farklı ve radikal etkiler yapabilmektedir. Jonas böyle durumlarda bu teknolojik ilerlemeye ve insani güçlere uygun olacak yeni bir etiğin yaratılması gerektiğini belirtmektedir. $\mathrm{Bu}$ dönemin etik buyruğu "öyle eyleyiniz ki, eylemlerinizin, hareketlerinizin sonuçları, gerçek insan yaşamının sürekliliği ile uyum halinde olabilsin" şeklindedir (Bauman, 2007:77). Jonas'ın ifadesinde ön görülebilme ve belirsizlikle şekillenen, korkunun dikkate alınması ve anlamlandırılması gerektiğini ve bu durumların sürekli dikkate alınması gerektiğinin düşünceden uzak tutulmaması gerektiğini, sistematik bir kötümserliğin sürekli zihnimizde, düşüncemizde bulunulması gerektiğini belirtmektedir. Bauman, Jonas'ın tespitlerine ek olarak savaş, doğanın yitimi, yoksulluğun artışı herkes tarafından olumsuz ve etik dışı gelişmeler olarak nitelendirilmesine rağmen yine de bu olgular ve olaylar dünyanın her köșesinde yeniden ve yeniden olduğunu belirtir. $\mathrm{Bu}$ gelişmeler, günümüzdeki insanlık haline ilişkin yaygın etik bir körlüğün oluşmasını sağlayan ve etiği görmezden gelmemize yol açan gelişmelerdir. $\mathrm{Bu}$ da her türlü müdahaleden uzak ve sadece rekabetin baskılarıyla, yönlendirmeleriyle motive edilen ve her geçen gün kontrolden çıkan, "aşkınlaşan" sermaye hareketleri ve dolaşımıdır. Bauman, bu düzlemde, "Postmodern etiğin" mümkünlüğü sorunsalını ortaya atmaktadır. Bauman, çağcıl dünyamız için etik düşüncesini farklılık çözümleri, özgürlük çözümlemeleri, yoksulluk çözümlemeleri ve dayanışma çözümlemeleriyle ele almaya çalışmaktadır. İnsanlık durumundaki mevcut çatışmaların giderilmesi, ortadan kaldırılabilmesinin yolunun oluşturmaya çalıştığı etik düşünceyle, kavrayışla aşmaya çalışmaktadır.

Levinas'ın belirttiği anlamda ahlaki sorumluluğun alınması ve bunun makro boyutta varlığını sürdürebilmesi için topyekûn bütün insanların haklarının teminat altına alınmasının sağlanması zorunludur. Bunun sağlanmasının ardından tahammül söz konusu olur. Farklılıkların yaşanması sağlanır. Makro boyutta etik sağlanır. Levinasçı anlamda dayanışma "o-nun için yaşamak"tır ve bunun sayesinde insan ben olabilir. Bauman için önce farklılıkların özgürlük içinde bir arada yaşaması gerekir, ardından dayanışmanın sağlanması ve makro etiğin oluşturulması beklenmektedir. $\mathrm{Bu}$ bekleme ve beklentiler devresi içerisinde sonucun ne olacağını tahmin etmek ve ön deyilerde bulunmak ve bir çözüm önerisinde bulunmak Bauman'ın düşüncesi içerisinde mümkün gözükmemektedir. Bauman'a göre bu durum "yalanc1 peygamberlik" pratiğidir (Bauman, 2002:51-65). Bauman, bu farklılıkların bir aradalığı ve olabilecekse dayanışma ve makro etiğin hayata geçirilmesi adaletli bir ekonomik sistemle söz konusu olabileceğine dair görüşlerini bildirir. Günümüzdeki etnik çatışmaların aslında sadece görünümde özcü niteliklere sahip olduğunu savunur. Bauman bu çatışmaların, kaynak paylaşımlarının eşitliğinin sağlanması, ekonomik üstünlüğün giderilmesi ve adaletin sağlanması ile bu çatışkıların giderilmesi mümkün görünmektedir.

Levinas'ın ben ve öteki çerçevesinde varolan etik sahnesinin mikro boyutta bırakmış olduğu etik kavrayışı, Bauman'da tüm dünya üzerinde adaletin yani makro, bütünsel etiğin sağlanmasını çabalamaktadır. $\mathrm{Bu}$ ahlak sahnesinin iki kişilik bir aradalığından toplumsal adalete gidilebilecek dönüşmesi beraberinde müphemliği ve belirsizliği de getirecektir. Bauman (2001:18) bunu şöyle ifade eder:

"Postmodernlik, ahlaki kişinin aynı anda hem baş belası hem de şansıdır ve de, postmodern durumun bu iki yüzünden hangisinin ayakta kalacağı da ahlaki bir sorundur.'

$\mathrm{Bu}$ postmodern siyaset, modernitenin temel düsturları olan "özgürlük, eşitlik ve kardeşlik" ilkelerinin yerini "özgürlük, farklılık ve dayanışma" üçlü ilkesine bırakması ile mümkün görünmektedir (Bauman, 2000:296).

\section{Genel Değerlendirme ve Tartışma}

Bu makale çerçevesinde; Bauman'ın özellikle Türkçe'ye çevrilmiş ve düşünümsellik konusunda önemli yerler tutan belirli metinleri üzerinden hareket edilmiştir. Bu bağlamda, Bauman değişen, farklılaşan dünya ve insanlık koşulları, durumları, kayganlaşan zeminler, modernitenin bilinen tüm referanslarının sorgulanıp kriz durumunun çözümlenmesi ve bütün bunların ötesinde farklı açılımlar, değerlendirmeler gerçekleştirme hususunda sosyal bilimlere modernitenin bilim anlayışından farklı sorumluluklar yüklemiştir ve farkındalık yaratmanın sosyal bilimlerin değerlendirmeleri ve çözümlemeleriyle yapılabileceğini düşünmüştür. $\mathrm{Bu}$ bağlamda sosyoloji ve soysal bilimlere büyük bir sorumluluk düşmektedir. Bu sorumluluk hem sosyoloji pratiğinin yerine getirilmesi hem de sosyoloji pratiğinin temel araştırma nesnesi konumundaki toplum, toplumsallık ve toplumsallığın oluşturduğu farklı ilişkisellikler açısından da önemlidir. Bu çerçevede bir entelektüel sorumluluk olarak, Bauman eserlerinde sınıf ilişkilerinden toplumsal cinsiyet ilişkilerine, etnisite tartışmalarından cemaatlere, kent planlarından, küreselleşmeye kadar modern yaşamın ve modernitenin hemen hemen her sosyolojik meselesine yer verir. Modernlik ve modernitenin kendisini ele alıp incelemeden ve eleştirel değerlendirmeye tabi tutmadan kanımca düşünümsellik ilkesi, sosyolojinin sosyolojisini yapmak pek olası görünmez.

Bauman tam da bu temelde, modernitenin geleneksel, Ortodoks, statik sosyal bilimler tartışmalarına ve kavramsallaştırmalarına girmekte, klasik sosyolojinin sınırlarını zorlamakta özellikle eserlerinde akademik sosyal bilim disiplinlerinin keskin sınırları arasında geçişlilik, belirsizlik, geçirgenlik niteliklerini ifadelendirmektedir. Bauman'ın (2011), "Sosyoloji” olarak kavramış olduğu alan topyekûn "Sosyal Bilimler" olmaktadır. Onun yazılarında, 
Toplumsal sistem, yap1, belirlilik, birey-toplum ve birey-yap1 gerilimi ve sınırlandırmalar, yerini, sürece, akışa, etkileşim, iletişim, toplumsallık, sosyallik, habitat, öz oluşum, öz toplanım, aylak, turist ve bunlar gibi kavramlar ve çözümlemelere bırakmıștır. Bu kavramlar ve çözümlemeler onun düşünümsellik çabasının yansımaları gibidir. Onun postmodernite kavrayışı da bu düşünümsellik çabası çerçevesinde değerlendirilebilir. Onun postmodernite kavrayışı "her şey uyar", "büyük anlatılar bitti”," her şey görelidir" savlarından farklı bir düşünceye işaret eder. Buna göre; Bauman, postmodern durum olarak nitelenen dönemdeki gelişmeleri, oluşumları değerlendirilirken akıcılık, süreklilik, akışkanlık, başka bir hale gelebilirlik temelinde incelemektedir. Bauman için sosyal bilimler, anlamları kapatmaz ya da dondurarak sabitleyemez. Sosyal bilimler gündelik yaşamla ilintili, bizatihi pratikle ilgili yorumlar toplamı olmaktadır. $\mathrm{Bu}$ nedenle "sosyolojik düşünmek" tek bir yoruma indirgenemeyerek, tek merkezli, sabit açıklamalardan uzaklaşarak çoklu yorumlar zemininde ele alınır. $\mathrm{Bu}$ durumda tek, hâkim ve yüce olarak nitelendirilebilecek açıklamalar ve yorumlardan ziyade bu açıklama ve yorumların birbirleriyle konuştukları, hiçbir anlayışın birbirini baskı altına almadığı müzakereye dayalı bir sosyolojik düşünmeden ve eylemeden bahseder.

Bauman için, sosyoloji ve tabii ki sosyal bilimler; insan eylemlerini, edimlerini, deneyimlerini geniş çaplı oluşumlar olarak kavrayan, görme alışkanlığını sağlayan, bu oluşumları karşılıklı bağımlılık ağına takılan aktörlerin rastlantısal olmayan birliktelik olarak kavranan alanlar niteliğini taşımaktadır (Bauman, 2011). Sosyal bilimciler, bu bağlılığı sağlayan durumu sağduyu olarak belirtirler ve onu anlamaya ve aşmaya çalışırlar. Sosyal bilimler, insanları sağduyusal bilgileri yeniden gözden geçirmeye, daha eleştirel bakmaya, onunla hesaplaşmaya sevk eder niteliktedir. Şeylerin görünenden veya görünmeyenden, inanılandan daha farklı, beklentilerin dışında olabilecekleri konusunda da Sosyal Bilimler farkındalık yaratmaktadır. Böylelikle Sosyal Bilimler belirlenimleri ortaya sermektedir. Bauman'ın bütün eserlerindeki ufuk, "ötekini" anlama ve "ötekini belirleyen anlam dünyasını" anlama çabası ve bununla birlikte modernitenin şiarı olan ben ve öteki arasındaki sınırların, duvarların aşılması çabasıdır. Bu durum Bauman'ı insan üzerinde düşünmeye odaklandırmakta ve bu tartışmalarla Antropoloji alanına da yaklaşan eleştirel bir yaklaşımı benimsemesine yol açmaktadır. Bu anlayış ve algılayış, insanın özgürlüğüne katkıda bulunmaktadır. Bir kişinin özgürlüğü başka bir kişinin özgürlüğünden üstün olmamaktadır. Farklı yaşam tarzları ve seçme özgürlüğünün gerçekleştirilmesi, genişletilmesi sayesinde kişilerin özgürlüğünden bahsetmek olasıdır. $\mathrm{Bu}$ da elbette onun postmodern etik olarak kavradığı bir zemin çerçevesinde düşünülebilir. Böylesine bir etiğe yaslanan bir düşünümsellik toplum olmanın ve bu oluşun bilimini yapmaya çalışan sosyolojinin ufkunu genişletir. Bu etik nosyonu hususunda belirli ayrım ve zorlamaların üstünden gelinebilir ve her şeyin ötesinde farklı farklı kişiler ve sosyalliklerden kurulu toplum düşüncesine katkı sunar. Elbette Bauman'ın bu yaklaşımı eleştire tabi tutulabilir ve çözüm önerileri olarak algıladığım etiğe saplanması ve onu diğer alanlardan bağımsızmış gibi sunması bu eleştirinin bazı noktalarını oluşturabilir. Ne ki, bana göre bütün dünya problemleri karşısında gerek toplumu oluşturan bireyler gerekse de bunun bilimsel pratiğini yerine getirmeye çalışan sosyoloji disiplinin düşünümselliği husussunda etik nosyon önemli bir başlangıç noktasını oluşturmaktadır. Kaldı ki, Bauman'ın etik kavrayışı politik olanla kurduğu bağlantılar sebebiyle Kant'ın etik anlayışından ayrılır ve temel ilkeleri bütün farklılıkları içinde sosyal olanı özgürlük, farklılık ve dayanışma ilkeleri çerçevesinde ele almaktır. Bauman'ın düşünümsellik ilkesi çerçevesinde ayrım noktasını tam da burada postmodern etik kavrayışında görmekteyim.

Bauman'ın iyimser bir tonda belirttiği üzere mevcut gelişmeler çerçevesinde farklılaşan sosyal bilimlerin, yukarıda bahsettiğimiz özgürlüğü göz önüne alarak tek tipte, tek boyuttaki yaşamı bizlere baskı ile kuran, oluşturan otoritelerin amaçlarını bozmakta olduğunu, hatta yıkıcı bir kuvvet olarak kendini kurmakta olduğunu belirtir. Bauman, bu hususta, Walter Benjamin'den tarih anlayışını devralarak yani onun "Tarih'in ihtimaller mezarlığı olduğu" fikrinden hareket ederek her çözüm önerisinin, her inancın kesin ve evrensel olmadığını yani kısmi ve perspektifsel, konumsal olduğunu bildirir ve her şeyin tartışmaya açık ve tartışmalı olduğunu düşünür (Bauman, 2011:60). Bu tartışma da sosyal bilimlerin düşünümselliğini oluşturan en önemli yerdir. Sosyal bilimlerin amacı, tarihin katliamından kurtulmuş olan, varlığını sürdüren ihtimalleri canlı tutmaya çalışmaktır. Bu canlı tutuş da elbette etik nosyondan bağımsız değildir. Buna göre Bauman'ın kavrayışına göre Tarih ve Sosyal Bilimler önceden verilmiş istikametleri olmayan bağımsız olaylar dizilerini oluşturmaktadırlar. $\mathrm{Bu}$ nedenle de bu alanların düşünümselliği daha dikkatli, daha çoklu, daha heterojen değerlendirmelere ve yorumlara kapı aralamak durumundadır.

\section{Kaynaklar}

BAUMAN,Z.(1996).Yasa Koyucular ve Yorumcular,(çev. K. Atakay), İstanbul: MetisYayınları

BAUMAN, Z.(1997). Özgürlük,(çev.:K.Eren), İstanbul: Sarmal Yayınları

BAUMAN, Z.(1998). Postmodern Etik, (çev.:A. Türker), İstanbul: Ayrıntı Yayınları.

BAUMAN, Z.(1999). Çalışma, Tüketicilik ve Yeni Yoksullar, (çev.: Ü. Öktem),İstanbul: Sarmal Yayınları

BAUMAN, Z. (1999).Küreselleşme, (çev.: A. Yılmaz), İstanbul: Ayrıntı Yayınları

BAUMAN,Z.

(2000).Postmodernlik ve Hoşnutsuzlukları,( çev.: İ. Türkmen), İstanbul. Ayrıntı Yayınları.

BAUMAN, Z.(2001). Parçalanmış Hayat,(çev.: İ. Türkmen), İstanbul: Ayrıntı Yayınları.

BAUMAN, Z.(2002) . Modernite,Postmodernite ve Etik. Doğu- Batı sayı:19, 51-61.

BAUMAN, Z.(2003). Modernlik ve Müphemlik, (çev.: İ. Türkmen), İstanbul: Ayrıntı Yayınları

BAUMAN, Z.(2007). Modernite ve Holocaust,(çev.: S.Sertabiboğlu), İstanbul: Versus Yayınları

BAUMAN, Z.(2011). Sosyolojik Düşünmek,(çev.: A. Yılmaz), İstanbul: Ayrıntı Yayınları

ÇIRAKMAN, E.(2000). Levinas'ta Öteki ve AdaletDoğuBatı, sayı:13,s.179-200. 
KARAKAYALI, N. (2007). Bourdieu, Adorno ve Sosyolojik Düşüncenin Sınırları (der.) G. Çeğin, E. Göker, A. Arlı ve Ü. Tatlıcan, Ocak ve Zanaat: Pierre Bourdieu Derlemesi içinde, İletişim yayınları: İstanbul.

LEVINAS, E.(2005). Zaman ve Başka,(çev.:Z. Direk),İstanbul: Metis Yayınları

SAYIN, Z. (2002). Başkalık Deneyimi. İstanbul: Yapı Kredi Yayınları 